\title{
Advancing Food Security through Agroecological Technologies: The Implementation of the Biointensive Method in the Dry Corridor of Nicaragua
}

\author{
Xavier Simon ${ }^{1, * \mathbb{D}}$, Maria Montero ${ }^{2}$ and Óscar Bermudez ${ }^{3}$ \\ 1 Department of Applied Economics, University of Vigo, 36310 Vigo, Spain \\ 2 Department of Economics, University of Vigo, 36310 Vigo, Spain; mmontero@uvigo.gal \\ 3 Amigos de la Tierra España, Managua 14027, Nicaragua; nicaragua@tierra.es \\ * Correspondence: xsimon@uvigo.gal
}

Received: 4 December 2019; Accepted: 21 January 2020; Published: 23 January 2020

check for updates

\begin{abstract}
In contrast with international food assistance programs, or with the new green revolution based on the sustainable intensification of agriculture, this work proposes an agroecological technology to overcome food insecurity problems in countries like Nicaragua, most especially in rural areas. In particular, it analyzes the effects of implementing the biointensive method—an agroecological food production initiative that is highly labor-intensive, but requires little land-in various communities of the Dry Corridor in Nicaragua. This project is the result of establishing an international consortium for development cooperation where grassroots communities played a prominent role. The main results are an improvement in local food security and a strengthening of the communities' capacity to face major challenges arising from poverty and climate change, the effects of which are increasingly noticeable in Central America. The main weakness identified is that the necessary tropicalization of the method has not been sufficiently tested, for a two-year period is too short a time to transform the prevailing rural development dynamics significantly.
\end{abstract}

Keywords: biointensive method; agroecology; food security; Nicaragua

\section{Introduction}

Despite the increment in global food production levels [1], it is estimated that the total number of undernourished people in the world has increased from around 804 million in 2016 to 821 million in 2017 [2]. In 2001 the head of the Agriculture and Rural Development Unit of the World Bank acknowledged that $70 \%$ of the poor lived in rural areas and that most of them were farmers [3]; thenceforth, the situation has evolved as shown by [4], who first introduced the "hungry farmer paradox".

This situation is common in Latin America and the Caribbean, and it has been proved that, in these regions, "extreme poverty in rural areas has been over two times as high as extreme poverty in urban areas in the last twenty years or more" [5]. In Nicaragua, poverty is concentrated in rural areas, where 1.2 million people, half of the population living in those regions, could still be considered poor in 2014, despite the significant reduction in their number during the last few years. These people represent $70 \%$ of the overall poor population in this Central American country [6]. In the Latin American and Caribbean context, "people are poor when individuals have a per capita income below USD 4 per person per day" [6].

The existence of poverty, food insecurity or undernourishment in rural areas is evidence of the profound inequalities and injustices created by the global food system. All these realities coexist with high levels of food waste [7], high proportions of the grain harvested used for animal feed and biofuel 
production [8], severe environmental impacts [9,10], and a strong institutional support to agro-export rather than to the national production of food for the local population [11].

On the other hand, the effects of climate change are expected to be harsher on poorer regions and subsistence farmers, like those living in Central America and in tropical and subtropical regions, including the Caribbean [12]. According to Economic Commission for Latin America and the Caribbean [13] in 2030 climate vulnerability will be higher in many countries within those regions, higher than it already is in Nicaragua, particularly in the areas along the Central American Dry Corridor [14].

Various strategies have been designed and implemented at different levels in order to correct this situation. Food assistance strategies supported by governments or international organizations have been useful to address urgent issues at specific moments $[15,16]$, but generally, these actions have not solved the structural problems behind poverty, malnutrition or hunger. An alternative solution is the one proposed by the second green revolution with the sustainable intensification of global agriculture, which would entail increasing productivity in poor countries through the use of modern technologies and practices $[17,18]$.

There is a third, different, alternative in agroecology. In the last few decades [19], various scientists, social movements and institutions have agreed on the need to move beyond the current agricultural models and develop new food systems. Agroecology is a science that studies and seeks to explain the functioning of agroecosystems, dealing primarily with biological, biophysical, ecological, social, cultural, economic and political mechanisms, functions, relations and designs [20,21]. It can also be understood as a set of practices that allow cultivating in a more sustainable way; a movement that brings together different actors for the purpose of developing sustainable agriculture; a scientific discipline that analyzes the way agroecosystems function [22]—or all of it at the same time.

It is within this field that we include the proposition for the transformation of the food system implemented in Nicaragua in the last two years. This proposition was designed by an international consortium of actors involved in the development of the biointensive method (BM) of food production. The BM can be considered a transformative agroecological strategy [23]; in other words, it is used as an alternative to industrial agriculture and as part of the struggle to challenge and change monoculture, dependence on inputs and the prevailing power structures. Its main objective is to locally produce healthy food that will be locally consumed, and thus, eradicate the food insecurity that low-income families with limited resources are facing every day. It is in this context, in which the presumed need to expand production can be reconciled with wider limits to sustainability [24], and the reconfiguration of the positions of the different actors within the food system [25], where we situate the concept of food security, therefore, beyond those perspectives that are solely focused on the sphere of food production or food demand.

During the last two years, this wide consortium has attempted to introduce the BM in poor communities of Nicaragua for the purpose of reducing food insecurity. The consortium, which was coordinated by the organization Amigos de la Tierra España in collaboration with Ecology Action and ECOPOL, used an international cooperation project financed by the Spanish Agency for International Development Cooperation to implement an agroecological strategy aimed at laying the foundations for the reduction of food insecurity in seven municipalities of Nicaragua. This article presents part of the social innovation process undertaken in this Central American country, and analyzes the challenges and critical points of such transformative strategy, which was collectively designed for a context that can be characterized as follows: (1) The families living in the rural municipalities involved in the project and their communities suffer from food insecurity, whether temporal or permanent; (2) the production methods and techniques used by the families do not enable them to produce enough to cover their food needs; (3) very often, those families have to face soil degradation processes, a factor that limits their capacity to produce food in a sustainable way; and (4) families living under those conditions (food insecurity and degraded soils) have a limited access to alternative information and knowledge that could help them manage their resources sustainably, and therefore, produce a significant part 
of their own food. Against this background, the biointensive method could significantly contribute not only to the production of more food in small land plots, but also to the improvement of the soil conditions and productivity.

This work is divided into the following sections. First of all, the biointensive method is described and characterized. The next section presents the case study of the implementation of the method in Nicaragua. Subsequently, the methodological proposal that has enabled the development of the social intervention project in the Dry Corridor of Nicaragua is explained. Finally, this research work ends with the presentation of the results and the drawing of the main conclusions.

\section{The Biointensive Method: Producing Quality Food in Contexts of Resource Scarcity}

The BM is considered one of many agroecological proposals aiming at transforming the present agrifood system. As indicated by La Vía Campesina, "the real solutions to the crises of the climate, malnutrition, etc., will not come from conforming to the industrial model. We must transform it and build our own local food systems that create new rural-urban links, based on truly agroecological food production by peasants, artisanal fishers, pastoralists, indigenous peoples, urban farmers, etc." [26]. The BM proposed by John Jeavons and inspired by the teachings of Alan Chadwick [27] is meant to produce this kind of transformation of the agrifood system, and is designed as a locally-based global food project. In fact, agroecology and its various technological propositions should not be understood as a collection of recipes to be applied any time in any place. On the contrary, " ... it is based on principles that, while they may be similar across the diversity of our territories, can and are practiced in many different ways, with each sector contributing their own colors of their local reality and culture, while always respecting Mother Earth and our common, shared values." [26]. The application of the $\mathrm{BM}$ to tropical regions shows, as we will see, that the typical rigidity of technological proposals is not compatible with all environmental or social circumstances.

Jeavon's method is both directly and indirectly based on many similar practices that have been developed in different parts of the world over thousands of years [28]. It promotes small-scale agriculture, which has proved to be five times more productive than conventional agriculture [28]. Quoting Robert Netting, Jeavons [28] affirmed that small-scale family agriculture is characterized by using simple tools, being labor-intensive, applying detailed knowledge of the local environment, and skillfully organizing and managing the production of local food for self-consumption with a surplus to be sold at the market or exchanged. It encourages the conservation of natural resources and tends to create social stability, due to the local control of land and labor. The BM aims at reproducing agricultural systems based on natural systems. For this purpose, it includes a series of "natural" practices: Plants should occupy all the space available, favoring the association of species, the roots of which will grow to reach a considerable depth; each land plot should produce the fertilizers required to replace that which has been absorbed by the plants grown therein. Therefore, $60 \%$ of the available area will be used for carbon farming (amaranth, corn, sorghum, sugar cane, jack bean, sesame...) and the production of fertilizers through composting processes; this carbon production will also provide calories for human consumption that will be complemented with those contained in root crops (potatoes, garlic, turnip, etc.) grown in a section occupying $30 \%$ of the culture area, while the remaining $10 \%$ will produce the minerals and vitamins required for a varied and balanced diet.

Agricultural systems based on natural systems can achieve larger economies of scale in the long term, as well as stronger levels of sustainability: Both environmental, because the soil as the fundamental basis of food production will keep its capacity intact, and social, because the production of enough food to provide a healthy and balanced diet will be guaranteed. Its objective is a global solution for the challenges that humanity is facing today and will be facing in the future [29]. The BM is expected to have the following effects in relation to conventional agriculture [30]:

A $200 \%$ to $400 \%$ increase of the calorie production by a unit of the area $[31,32]$. This will allow "liberating" one part of the territory to help preserve biodiversity: The reduction of the land footprint 
by at least 50\% would make it possible [29]. For instance, [33] reports increments of productivity of between $149 \%$ and $59 \%$ for, respectively, radish and beans grown in Mexico.

A $67 \%$ to $88 \%$ reduction in the consumption of water per unit of production [31].

A $100 \%$ increase of soil fertility in the C soil horizon, measured through its carbon content, which allows cultivating the soil sixty times faster than normal [29].

A $56 \%$ to $100 \%$ reduction of the amount of organic fertilizer purchased per unit of production.

A $99 \%$ reduction of the amount of energy used per unit of production. [34] has shown, through detailed calculations on onion production systems, how biointensive production reduces the dependence of the food system on fossil fuels.

A $100 \%$ increase in the revenues obtained per unit of area.

This method makes it possible to produce, within an area of $371 \mathrm{~m}^{2}$ located on the northern coast of California, all that is necessary for one person's full diet for one year [30]. The challenge is to produce enough food for everyone without destroying our resources, and the BM could be part of the solution to this problem. [29] states that a biointensive design of 10 beds can feed between 20 and 65 people within the same area that is required today to feed an average citizen of the United States. These data confirm the potential of the BM to contribute to the solution of food problems affecting millions of people in the world, particularly poor farmers in poor countries. As mentioned before [35], the majority of hungry and poor people live in rural, agriculture-dependent areas. The BM is also a useful technology in societies where land and resources are too limited to apply the patterns of marketization associated with modern agriculture, the green revolution and other sustainable intensification proposals.

Similarly to other agroecological practices (intercropping; the integration of crops, trees, animals and fish; green fertilizers; composting; etc.), the BM is based on ecological principles, such as the conservation of soil life, the recycling of nutrients, the dynamic management of biodiversity, and the conservation of energy at all levels. The BM is based on the application of eight basic principles and one design principle [36]. The basic principles are: Deep soil preparation, composting, intensive planting, companion planting, carbon farming, calorie farming, seed saving, and a whole-system perspective. The design principle requires distributing the land available according to this rule $-60 \%$ of the growing area for calorie-dense crops, $30 \%$ for high calorie-producing crops, and 10\% for vegetable crops rich in important vitamins and minerals.

\section{The Case Study: The Application of the BM to Three Territories in Nicaragua}

\subsection{The Territories}

The BM has been implemented in seven municipalities of three different territories in Nicaragua: Los Guatuzos (Department of Río San Juan), a humid tropical territory; Altagracia and Moyogalpa, in the island of Ometepe (Department of Rivas), a semi-humid tropical territory; and Totogalpa, Las Sabanas, San Lucas and Somoto (Department of Madriz), a dry tropical territory (Figure 1). As many as 142 producers ( 75 of whom were women) from 45 different communities within those seven municipalities participated in the project. 


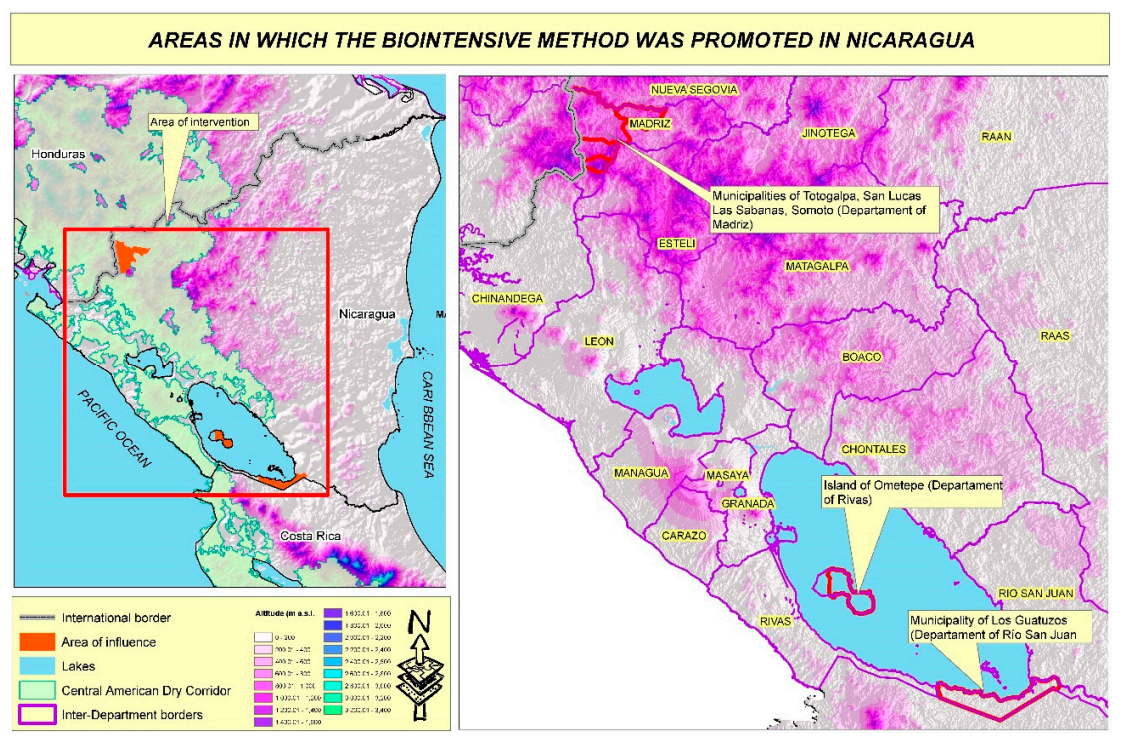

Figure 1. Map of the territories where the BM was implemented.

Source:

Municipality and Department borders, were obtained from https://ineter.gob.ni/.

Altitude layer was obtained from https://earthexplorer.usgs.gov/. We use Global Topographic 30 Arc-Second Digital Elevation Model (Released 1996).

Dry corridor layer was obtained from https://www.arcgis.com/home/item.html?id= fde0c585ebcc4a3098c08c8062dfba06 and from https://www.arcgis.com/home/webmap/viewer.html? webmap=fde0c585ebcc4a3098c08c8062dfba06.

The territories reflect the great diversity of climates of Nicaragua: Dry, humid and semi-humid tropical climates, with widely differing rainfall patterns and land uses, as shown in Table 1. Although the three territories are similar in terms of forest presence, the cultivation of basic grains and vegetables is more important in Madriz and Ometepe (23\% and 28\%, respectively) than it is in Río San Juan $(14 \%)$. However, permanent crops (coffee, bananas, avocado, watermelon, tobacco) represent a much higher proportion of the overall production in Ometepe (27\%) than in Madriz (6\%) or Río San Juan $(7 \%)$. This asymmetry is also evident in relation to the presence of natural pastures: Barely $11 \%$ of the territory of Ometepe is dedicated to this use, while they occupy 31\% of the land in Madriz and 39\% in Río San Juan. It is important to mention that Los Guatuzos (Río San Juan) is the only territory located within an agricultural frontier area; this is why access to land is not the main limiting factor in this region, and the implementation of this method of production in small plots has proved to be somehow contrary to the local tradition.

Table 1. Main characteristics of the territories where the BM has been implemented.

\begin{tabular}{cccc}
\hline & Madriz & Ometepe & Río San Juan \\
\hline Climate & Dry tropical area & Semi-humid tropical area & Humid tropical area \\
Average altitude $(\mathrm{m}$ & 862 & 58 & 5 \\
a.s.l.) & 1104 & 1500 & 2005 \\
Rainfall (mm/year) & & \\
\hline
\end{tabular}


Table 1. Cont.

\begin{tabular}{cccc}
\hline & Madriz & Ometepe & Río San Juan \\
\hline \multicolumn{2}{c}{ Land use (\%) } & \\
\hline annual crops & 17 & 13.5 & 9.2 \\
permanent crops & 10.5 & 11.5 & 3.9 \\
cultivated pasture & 10.4 & 14.4 & 20.1 \\
natural pasture & 26.7 & 26.9 & 40.3 \\
forest areas & 12 & 17.5 & 11 \\
fallow land & 19.8 & 13.5 & 11.1 \\
Infrastructures and roads & 1.3 & 1.6 & 0.9 \\
Water areas & 2.3 & 1.1 & 3.5 \\
& 100 & 100 & 100 \\
\hline & Land distribution (\% farms) & 11 \\
\hline 0.7 ha & 26 & 29 & 14 \\
$3.5 \leq$ area $<3.5$ & 46 & 45 & 14.5 \\
$\geq 7$ & 12 & 17 & 60.5 \\
\hline
\end{tabular}

Source: Several statistical publications retrieved from http://www.inide.gob.ni/, the website of the Instituto Nacional de Información de Desarrollo (National Institute of Development Information).

As observed in Table 1, the structure of the farms is very similar in Madriz and Ometepe, with farming families owning less than 3.5 hectares of agricultural land ( $72 \%$ and $74 \%$, respectively). In contrast, farms in Río San Juan are predominantly larger, over 7 hectares. This situation coexists with a growing agricultural intensification in farms of more than 2000 hectares producing cattle, rice and beans. For instance, at the Río San Juan Biosphere Reserve, the area dedicated to crop and livestock activities increased from representing $32 \%$ of the territory in 2000 to reach $48 \%$ in 2018 [37].

\subsection{The Families}

Under the direction of Amigos de la Tierra España, and in collaboration with the local organizations in each territory, the farming families participating in the initiative (142) were selected according to criteria based on local leadership; women's involvement in family survival responsibilities; environmental sensitivity and interest in small-scale production; food insecurity and high vulnerability to risks associated with climate change.

From the beginning the project applied a gender perspective, promoting women's participation in training activities, defining work at the biointensive gardens as a task to be shared among all family members, and fostering reflection about the distribution of roles in the performance of housework at the different workshops and focus groups.

The families participating in the project were either medium-sized or large: The average number of persons in the household was five-six on the island of Ometepe. They were all young families: In Ometepe and Río San Juan, members under fifty years of age represented 70\%, while in Madriz they reached $85 \%$. If we consider the totality of family members, $40 \%$ of them were under twenty years.

Despite differences in terms of global property structure, as mentioned before, $28.9 \%$ of the families involved in the project owned less than 0.7 hectares, $49.4 \%$ of them owned between 0.7 and 3.5 hectares, and $21.7 \%$ had farms more than 3.5 hectares big. In other words, most producers selected to participate in the project in all three territories were subsistence farmers with little land. They were engaged in conventional agricultural practices, particularly the sowing and production of basic grains: Corn, beans, rice, and sorghum.

With regard to access to water, even though $74.7 \%$ of the participants had water sources within their farms, which they used both for irrigation and family consumption, in Ometepe the percentage barely exceeded 37\%, while in Madriz it rose to $95 \%$. 


\subsection{The Consortium}

This study is linked to an international cooperation project led by Amigos de la Tierra España. The project was totally funded by the Spanish Agency for International Development Cooperation. The only interest of the consortium members was to accomplish the main objective of the project: To promote the BM in order to produce, within a two-year period, sufficient and appropriate food for the communities participating in the initiative. The main objective was to promote the BM in order to produce, within a two-year period, sufficient and appropriate food for the communities participating in the initiative. The project was to be carried out in a context of economic and food crisis, and aimed at strengthening the resilience of local communities. For this purpose, an international consortium was established by the following partners (see Table 2):

Table 2. Structure of the consortium for the implementation of the BM in Nicaragua.

\begin{tabular}{|c|c|c|}
\hline Actor & Role & $\begin{array}{l}\text { Connection with the } \\
\text { other Actors }\end{array}$ \\
\hline Amigos de la Tierra España & $\begin{array}{l}\text { General coordination of the project; conduction of } \\
\text { surveys; coordination of focus groups; } \\
\text { conduction of in-depth interviews: Coordination } \\
\text { with the communities in Río San Juan; training of } \\
\text { participants; field school in Río San Juan }\end{array}$ & All the other actors \\
\hline $\begin{array}{l}\text { Universidad Nacional } \\
\text { Agraria (UNA) }\end{array}$ & $\begin{array}{l}\text { Training of the technicians participating in the } \\
\text { project at the Centro de Capacitación, } \\
\text { Investigación y Demostración del Método } \\
\text { Biointensivo en Nicaragua }\end{array}$ & $\begin{array}{l}\text { Ecology Action; Ecología y } \\
\text { Población; trainees }\end{array}$ \\
\hline $\begin{array}{l}\text { Instituto de Promoción } \\
\text { Humana (INPRHU) }\end{array}$ & $\begin{array}{l}\text { Coordination with the communities in Madriz; } \\
\text { training of participants; field school; participant } \\
\text { observation; local focus group }\end{array}$ & $\begin{array}{l}\text { Communities of the } \\
\text { municipalities of } \\
\text { Totogalpa, San Lucas, } \\
\text { Las Sabanas and Somoto }\end{array}$ \\
\hline $\begin{array}{l}\text { Fundación Entre Volcanes } \\
\text { (FEV) }\end{array}$ & $\begin{array}{l}\text { Coordination with the communities of Rivas; } \\
\text { participant observation; local focus group }\end{array}$ & $\begin{array}{l}\text { REMO; communities of } \\
\text { Altagracia and Moyogalpa }\end{array}$ \\
\hline $\begin{array}{l}\text { Red de Mujeres de } \\
\text { Ometepe (REMO) }\end{array}$ & $\begin{array}{l}\text { Training of participants; field school; local focus } \\
\text { group }\end{array}$ & $\begin{array}{l}\text { Communities of Altagracia } \\
\text { and Moyogalpa }\end{array}$ \\
\hline $\begin{array}{l}\text { Families participating } \\
\text { in the project }\end{array}$ & $\begin{array}{l}\text { Participation in the design, implementation and } \\
\text { assessment of the biointensive method }\end{array}$ & $\begin{array}{l}\text { All the other actors } \\
\text { operating in their } \\
\text { respective territories }\end{array}$ \\
\hline University of Vigo (UV) & Monitoring of the project & All the other actors \\
\hline
\end{tabular}

Amigos de la Tierra España was responsible for leading the project. Its 25-year-long experience was key for the governance of the consortium and the design of the strategies required to attain the goals initially defined. This organization has focused its efforts on creating spaces for food sovereignty [38], and generating discourses and practices for the transformation of the global food system [39]. Amigos de la Tierra España has a team of local experts and leaders working on-site in Central America, who were the driving force behind the implementation and development of this project in Nicaragua. These experts speak the same language as the local communities, and they rapidly identified the limitations and weaknesses of the initial plan of this new food strategy, therefore, facilitating its adaptation and dynamization. Amigos de la Tierra España also performed other specific roles in relation to the communities of Los Guatuzos.

The Universidad Nacional Agraria (UNA, National Agricultural University) was in charge of coordinating the intervention of members of international reference organizations for the BM-Ecology Action (http://growbiointensive.org/), in the United States, and Ecología y Población (http://biointensivistas.ning.com), in Mexico-in the training of local technicians. This training took place at the university's Centro de Capacitación, Investigación y Demostración del Método Biointensivo 
(Center for the Training, Research and Demonstration of the Biointensive Method), which is also a reference institution for biointensive training in Central America.

The Instituto de Promoción Humana (INPRHU, Human Promotion Institute, based in Somoto) is a reference organization in northern Nicaragua that, during the last two decades, has promoted alternative food production systems among small-scale producers. The INPRHU has two centers of reference and biointensive agroecological gardens in the municipalities of Telpochcalli and Somoto, where the main research, experimentation and dissemination activities regarding the BM in the Dry Corridor of Nicaragua are carried out. Like the other local agents, the INPRHU was responsible for coordinating the focus groups and all local actions in the department of Madriz.

The Fundación Entre Volcanes (FEV) is the reference organization in the island of Ometepe in all matters concerning the promotion of food security at a biointensive training and research center, which is linked as well to the Red de Mujeres de Ometepe (REMO, Ometepe Women's Network). As an organization, REMO is focused on defending women's rights in the island, but it became the actual catalyzer of the implementation of the BM in the area, as well as coordinator of the field school.

The University of Vigo (Spain) has carried out strategical analysis and monitoring actions to assess the progress made in the implementation of the method. Its members have participated in various workshops on-site and have moderated various dialogue workshops for the different actors involved in the project.

\section{A Participatory Methodology}

Understanding sociopolitical dynamics in different and complex environmental and social contexts requires, from our point of view, abandoning rigid methodological proposals framed within one single discipline or designed from one single (quantitative or qualitative) methodological perspective. This is a basic principle of this research work. The implementation of the BM in all three Nicaraguan territories was assessed by using a set of mixed research methods (see Table 3). We borrow this concept from [40], who affirmed that mixed research methods are an intellectual synthesis based on qualitative and quantitative research. In our work, we have used key informant interviews with social leaders identified as such in previous cooperation actions, participant observation, workshops, and focus groups as the main qualitative sources, as well as surveys of the participants, from which we drew quantitative information. In addition, we have reviewed scientific documents gathered from the most common sources, such as the Web of Science, relevant reports from international organizations, and various internal reports generated by the organizations involved in the project.

An initial survey was conducted in April 2017 with all the participating families (142). The families were required to own land that was available to develop the method and to have at least one adult member who could act as the family leader in the process of learning and developing the method.

The results were useful to plan the strategy for the implementation of the BM in each territory. Field schools were started in the three regions; they combined the dissemination of the main BM techniques with the teaching imparted by professors of the Universidad Nacional Agraria and experts of other organizations, who also adapted the strategies to the particularities of the different territories. The schools applied a participatory training methodology in the thirteen seminars on different issues (Preparing the seed for sowing, Efficient water management; Use of creolized seeds; Association and rotation; Composting; Carbon and energy farming; Double digging; Biointensive garden and edible forest; Ecological pest management; Planning; Sustainable soil) offered during the first year.

This methodology and the actual exchange between farmers have proved to be an excellent means of sharing information and transferring knowledge and technology in the peasant world [41]. Such factors as a fluent dialogue among farmers and the transfer of knowledge (not only about soils and climate, but also about social and economic issues) validated under similar conditions make it easier for the farmers to accept and incorporate technological modifications like those proposed by the BM. 
Table 3. Summary of the methods used in the research.

\begin{tabular}{|c|c|c|c|c|}
\hline $\begin{array}{c}\text { Research } \\
\text { Method/Number of } \\
\text { Times it was Applied }\end{array}$ & $\begin{array}{c}\text { Gathered } \\
\text { Information }\end{array}$ & $\begin{array}{l}\text { When it was } \\
\text { Gathered }\end{array}$ & $\begin{array}{c}\text { Who was } \\
\text { Responsible for it }\end{array}$ & $\begin{array}{c}\text { What it } \\
\text { Contributed to }\end{array}$ \\
\hline $\begin{array}{l}\text { Initial survey/142 } \\
\text { interviews }\end{array}$ & $\begin{array}{l}\text { Initial situation: } \\
\text { Social, economic } \\
\text { and environmental } \\
\text { information }\end{array}$ & April 2017 & $\begin{array}{l}\text { Amigos de la Tierra } \\
\text { España, in } \\
\text { coordination with } \\
\text { INPRHU and FEV, } \\
\text { for the execution; } \\
\text { UV and Amigos de } \\
\text { la Tierra España for } \\
\text { the design and } \\
\text { analysis }\end{array}$ & $\begin{array}{l}\text { Identifying the } \\
\text { main problems; } \\
\text { capturing the social } \\
\text { perception of } \\
\text { possible } \\
\text { alternatives }\end{array}$ \\
\hline $\begin{array}{c}\text { Participant } \\
\text { observation/ Ongoing }\end{array}$ & $\begin{array}{l}\text { Existence of } \\
\text { training } \\
\text { deficiencies; } \\
\text { identification of } \\
\text { community } \\
\text { leadership; } \\
\text { existence of local } \\
\text { conflicts }\end{array}$ & 2017-2019 & $\begin{array}{l}\text { INPRHU, FEV, } \\
\text { REMO, Amigos de } \\
\text { la Tierra España, } \\
\text { UV }\end{array}$ & $\begin{array}{l}\text { Completing } \\
\text { quantitative } \\
\text { information; } \\
\text { identifying the } \\
\text { roles played by the } \\
\text { different family } \\
\text { members }\end{array}$ \\
\hline $\begin{array}{l}\text { Key informants/ six } \\
\text { in-depth interviews }\end{array}$ & $\begin{array}{l}\text { Knowledge about } \\
\text { complex social } \\
\text { processes in local } \\
\text { communities; } \\
\text { social division of } \\
\text { labor }\end{array}$ & 2017-2019 & $\begin{array}{l}\text { Amigos de la Tierra } \\
\text { España, FEV, } \\
\text { INPRHU }\end{array}$ & $\begin{array}{l}\text { Playing down the } \\
\text { role of the BM in } \\
\text { families and } \\
\text { communities; } \\
\text { identifying the role } \\
\text { played by the BM } \\
\text { in relation to family } \\
\text { shortfalls }\end{array}$ \\
\hline $\begin{array}{l}\text { Focus groups/ } 3 \text { at the } \\
\text { beginning and } 3 \text { at the } \\
\text { end }\end{array}$ & $\begin{array}{l}\text { Collective } \\
\text { verification of } \\
\text { evidence gathered } \\
\text { from other sources }\end{array}$ & 2017-2019 & $\begin{array}{l}\text { Amigos de la Tierra } \\
\text { España, FEV, } \\
\text { INPRHU }\end{array}$ & $\begin{array}{l}\text { Consolidating the } \\
\text { diagnosis of the } \\
\text { BM; detecting } \\
\text { malfunctions in the } \\
\text { BM; forecasting } \\
\text { future lines of } \\
\text { action }\end{array}$ \\
\hline $\begin{array}{l}\text { Workshops/ } 4 \text { in all, } 1 \\
\text { in each territory and } 1 \\
\text { on a national scale }\end{array}$ & $\begin{array}{l}\text { General } \\
\text { information on } \\
\text { communities, local } \\
\text { processes, social } \\
\text { relations, } \\
\text { governance }\end{array}$ & 2018 & $\begin{array}{l}\text { Amigos de la Tierra } \\
\text { España, INPRHU, } \\
\text { FEV, the } \\
\text { participation of the } \\
\text { UV }\end{array}$ & $\begin{array}{l}\text { Putting the families } \\
\text { and their } \\
\text { communities into } \\
\text { their social, } \\
\text { economic and } \\
\text { environmental } \\
\text { context }\end{array}$ \\
\hline $\begin{array}{c}\text { Final survey/ } 142 \\
\text { interviews }\end{array}$ & $\begin{array}{l}\text { Social and } \\
\text { economic } \\
\text { dynamics of the } \\
\text { participating group }\end{array}$ & March 2019 & $\begin{array}{l}\text { Amigos de la Tierra } \\
\text { España, together } \\
\text { with INPRHU and } \\
\text { FEV, for the } \\
\text { execution; UV and } \\
\text { Amigos de la Tierra } \\
\text { España, for the } \\
\text { analysis of the } \\
\text { results }\end{array}$ & $\begin{array}{l}\text { Conclusions about } \\
\text { the application of } \\
\text { the BM; results of } \\
\text { the implementation }\end{array}$ \\
\hline
\end{tabular}

On the other hand, ongoing participant observation (PO), for which the local technicians of INPRHU, FEV, REMO and Amigos de la Tierra España were responsible, helped detect deficiencies in training that improved the design of later training activities, identify possible conflicts within communities, or between the latter and third parties, and deactivate them, which was key to face the 
subsequent phases of the project. In addition, PO allowed identifying the key informants, as well as discerning the dynamics that helped conduct both the focus groups, more specific and concentrated on the practical aspects of the application of the $\mathrm{BM}$, and the workshops, more general and open to wider participation, as well as to the discussion of issues not necessary related to the BM.

Observing the experience of different producers in different regions provides many learning opportunities, which may be richer and more useful than those offered at centers of reference like the one run by the UNA. When compared to the training centers, the producers' land plots have the advantage of being developed under conditions that are closer to those of other producers. In contrast, the farmers do not have as many resources or as much time available as institutions like the UNA have to manage the gardens, monitor the tests of new crops, or experiment with specific techniques or practices.

In addition, there were six in-depth interviews conducted with local actors (three at the beginning of the project and three at the end), and four workshops organized: Three for the local communities of each territory, and one on a national scale, in which the families and groups from all three territories participated together with all the organizations involved in the consortium.

Finally, six focus groups were created, two on each territory, with eight to ten participants in each group. The first meeting was more open and general, but for the second one, at the end of the implementation, the participants were selected according to stricter criteria: Balance between men and women; active involvement from the beginning; development of three or more production cycles; seed production; representation of the different agroecological areas within the same territory, etc. The work with these final focus groups provided information about the local perception of change, the actual scope of the implementation, the difficulties encountered, and the relevant learnings obtained from experience. This qualitative information was complemented with the conduction of a survey at the end of the project (142 interviews), the quantitative results of which completed the global diagnosis concerning the application of the BM.

During the whole process of implementation of the BM and systematization of the results, the Internet (through Skype and Webex Meetings) was used, but all actions involving the families' participation were performed in person. Whatsapp groups were also used as a means of contact among participants. Records were kept of all the topics discussed in every meeting, focus groups or workshop. All this material was systematized and served as a basis for the drafting of several documents at the initial, intermediate and final phases of the project, from which many of the results presented below are drawn.

\section{Results and Discussion}

The main achievements of the implementation of the BM in the agricultural communities of seven municipalities in Nicaragua can be summarized as follows (partially derived from Supplementary Materials).

First of all, food availability and variability have increased among the families; food security has consequently improved as well, as we can observe in Table 4 . Families have augmented by $187 \%$ the crop diversity, rising from 15 to 43 crops. The improvement in food diversity was especially relevant during the second year of the project, with an average incorporation of 3-4 new foodstuffs. First of all, food availability and food diversity have both increased among the families; food security has consequently improved as well. Families in all territories have augmented their crop diversity by $87 \%$, rising from 23 to 43 total crops. The improvement in food diversity was especially significant during the second year of the project, with an average incorporation of 3-4 new foodstuffs per family. 
Table 4. A number of crops incorporated through the Biointensive Method by territory.

\begin{tabular}{cccc}
\hline Territories & $\begin{array}{c}\text { Number of Crops } \\
\text { before the Project }\end{array}$ & $\begin{array}{c}\text { Number of Crops after } \\
\text { the Project }\end{array}$ & Variation (\%) \\
\hline Madriz & 23 & 30 & $30 \%$ \\
\hline Ometepe & 13 & 26 & $100 \%$ \\
\hline Guatuzos & 11 & 31 & $181 \%$ \\
Total & $\mathbf{2 3}$ & $\mathbf{4 3}$ & $\mathbf{8 7 \%}$ \\
\hline
\end{tabular}

Source: Data drawn from the two surveys conducted in the three territories at the beginning and the end of the project.

Even if the project was meant to apply the $60 \%-30 \%-10 \%$ basic rule, the social and agroecological reality of families and territories generated a different crop distribution. Most crops actually sown in the beds belonged to the vitamin group, when this group was supposed to occupy only $10 \%$ of the total area. The final survey indicates that only $30.28 \%$ of the land was cultivated with carbon crops, while $29.89 \%$ was given to calorie crops and $39.83 \%$ to vitamin crops (see Table 5). This modification was particularly evident in Madriz and Los Guatuzos, where vitamin crops covered, respectively, $44 \%$ and $47 \%$ of the garden area. In Ometepe more carbon crops were cultivated than in the other two territories; they occupied $40 \%$ of the land.

Table 5. Crop distribution in the growing area according to the 60-30-10 sustainability formula.

\begin{tabular}{|c|c|c|c|c|c|c|c|c|}
\hline \multirow{2}{*}{ Category } & \multicolumn{2}{|c|}{ Madriz } & \multicolumn{2}{|c|}{ Ometepe } & \multicolumn{2}{|c|}{ Guatuzos } & \multirow{2}{*}{$\frac{\text { Total }}{\text { Area }\left(\mathrm{m}^{2}\right)}$} & \multirow{2}{*}{$\%$} \\
\hline & Area $\left(m^{2}\right)$ & $\%$ & Area $\left(m^{2}\right)$ & $\%$ & Area $\left(\mathrm{m}^{2}\right)$ & $\%$ & & \\
\hline Carbon & 305.0 & $24 \%$ & 388.0 & $40 \%$ & 107.0 & $26 \%$ & 800.0 & $30.0 \%$ \\
\hline Calories & 413.5 & $32 \%$ & 268.0 & $28 \%$ & 108.4 & $27 \%$ & 789.9 & $30.0 \%$ \\
\hline Vegetables & 560.0 & $44 \%$ & 302.0 & $32 \%$ & 190.4 & $47 \%$ & 1052.4 & $40.0 \%$ \\
\hline Total & 1278.5 & $100 \%$ & 958.0 & $100 \%$ & 405.8 & $100 \%$ & 2642.3 & $100 \%$ \\
\hline
\end{tabular}

The fact that the initial $60 \%$ proportion of carbon crops was not respected may cause the collapse of the biointensive system in the next years, as shown by [42]. The shortage in carbon crop production was complemented with the collection of stubble from conventionally farmed plots to be composted, rather than burned as before. Producers prioritized vitamins as a strategy to guarantee self-consumption. The families' socioeconomic conditions have an influence on their perception and adoption of new techniques, as well as on their involvement in new agroecological initiatives. Their short-term interest is connected to their search for solutions for their food-related needs, although those solutions may hinder the sustainability of the method: No other factor can overshadow the goal of survival. Eating comes first, as some participants put it both in the focus groups and the in-depth interviews.

This focus on the production of vitamins reduced by $41.9 \%$ the scarcity of food in the households, given that $74.7 \%$ of the interviewees mentioned their food shortages at the beginning of the process, while two years later only $43.4 \%$ of them affirmed to be suffering from lack of food (see Table 6 ). It is important to underline that the diversification of the food production contributed to comply with the fundamental principles of food and nutritional security: Food availability, physical and economic access to it and consumption of high-quality and safe food.

Secondly, progress has been made in the valuation of women's role in the economic development of their families, beyond domestic work. The establishment of biointensive gardens has favored the integration of all family members in the management of the various activities required in the garden (preparing of beds, irrigation, pest control, etc.). Women were present in the decision-making processes concerning the application of the method to their farms; they had access to training and exchanges. Family relationships improved because of parent-children interaction for the distribution of roles 
and tasks in the garden, and this is important because success in the implementation of the different practices depends on a change in people's attitude and teamwork. In addition, it is worth highlighting some young people's enthusiasm about the BM: "I never thought it could be so useful to improve my family's food production", or "I am looking for a land plot to work and help out my family with the food" are some of the statements that these young people made at the workshops.

Table 6. Changes in food shortages by territory.

\begin{tabular}{ccc}
\hline Territories & $\begin{array}{c}\text { \% Families Suffering from Food } \\
\text { Shortages at the Beginning of the Process }\end{array}$ & $\begin{array}{c}\text { \% Families Suffering from Food } \\
\text { Shortages at the End of the Process }\end{array}$ \\
\hline Madriz & 74.4 & 43.6 \\
Ometepe & 77.8 & 44.4 \\
Guatuzos & 70.6 & 41.2 \\
Total & 74.7 & 43.4 \\
\hline
\end{tabular}

Source: Data drawn from the two surveys conducted in the three territories at the beginning and the end of the project.

This came together with, in the third place, the diversification of the families' sources of income. Even if the main family income still comes from conventional agricultural practices at the family farm, the implementation of the BM has resulted in new incomes obtained from the surplus production at the garden. One third of the families (33.7\%) managed to produce surpluses and sell them to buy other household consumption products they could not produce in their gardens. Moreover, at least $50 \%$ of women, as compared to the total number of participants, have now greater access and control of the family income, due to the sale of those surplus products. Some studies have shown that when women's economic contribution is greater, families are less exposed to food insecurity [43].

Fourth, self-sufficiency in seed production had increased significantly among the families by the end of the project. Up to $50.0 \%$ of the final survey respondents mentioned they produced corn seeds in their gardens, while $51.2 \%$ of them produced bean seeds, and $82.2 \%$ seeds of various vegetables, as we can observe in Table 7.

Table 7. Percentage of families producing seeds.

\begin{tabular}{ccccc}
\hline & Madriz & Ometepe & Guatuzos & Total \\
\hline Corn & 89.7 & 22.2 & 0 & 50.0 \\
Beans & 94.9 & 14.8 & 6.3 & 51.2 \\
Sorghum & 10.3 & 3.7 & 0 & 6.1 \\
Vegetables & 100 & 61.1 & 62.5 & 82.2 \\
\hline
\end{tabular}

Source: Data drawn from the final survey conducted in the three territories at the end of the project.

This is a key aspect of any agroecological proposal: Families produce their own creolized seeds from the new seeds facilitated at the beginning of the project. In addition, community seedbanks have been created in all three territories, which will supply other producers in the community, thus, favoring continuity in the application of the BM. The results show that women are the most active agents in the reproduction and custody of those new seeds.

Fifth, a thorough transformation of the fertilization processes has taken place. On the one hand, waste management has been improved through the introduction of recycling systems allowing the transformation of waste into organic fertilizers. Even though at the beginning of the project only $34.9 \%$ of the families performed this kind of practice ("we used to burn or throw away the waste before"), two years later $86.7 \%$ had adopted it. This good result is a consequence of the training received at field school and of the monitoring carried out by the technicians of the consortium. Most participants in the focus groups, as well as the key informants, manifested their surprise at discovering that "compost is the magic recipe for cultivating soil", which helps improve the output. 
The annual yields by type of crop were considerable (see Table 8): In carbon crops, the yield per unit of area was $0.76 \mathrm{~kg} / \mathrm{m}^{2}$, while for calorie crops it reached $2.61 \mathrm{~kg} / \mathrm{m}^{2}$, and for vitamin crops $3.87 \mathrm{~kg} / \mathrm{m}^{2}$. These yields were much higher than the maximum yields in the Central American region, where, for instance, the yield of corn is close to $0.3 \mathrm{~kg} / \mathrm{m}^{2}$, and that of beans just below $0.1 \mathrm{~kg} / \mathrm{m}^{2}$ [41].

Table 8. Crop yields by group. Results by territory.

\begin{tabular}{|c|c|c|c|c|c|c|c|c|c|}
\hline \multirow[b]{2}{*}{ Category } & \multicolumn{3}{|c|}{ Madriz } & \multicolumn{3}{|c|}{ Ometepe } & \multicolumn{3}{|c|}{ Guatuzos } \\
\hline & $\begin{array}{l}\text { Area } \\
\left(\mathrm{m}^{2}\right)\end{array}$ & $\begin{array}{l}\text { Production } \\
\text { (kg) }\end{array}$ & $\begin{array}{l}\text { Yield } \\
\left(\mathrm{kg} / \mathrm{m}^{2}\right)\end{array}$ & $\begin{array}{l}\text { Area } \\
\left(\mathrm{m}^{2}\right)\end{array}$ & $\begin{array}{l}\text { Production } \\
\text { (kg) }\end{array}$ & $\begin{array}{l}\text { Yield } \\
\left(\mathrm{kg} / \mathrm{m}^{2}\right)\end{array}$ & $\begin{array}{l}\text { Area } \\
\left(\mathrm{m}^{2}\right)\end{array}$ & $\begin{array}{l}\text { Production } \\
\text { (kg) }\end{array}$ & $\begin{array}{l}\text { Yield } \\
\left(\mathrm{kg} / \mathrm{m}^{2}\right)\end{array}$ \\
\hline Carbon & 305 & 273.28 & 0.89 & 388 & 279.63 & 0.72 & 107 & 64.86 & 0.60 \\
\hline Calories & 413.5 & 1084.08 & 2.62 & 268 & 728.46 & 2.71 & 108.4 & 279.68 & 2.58 \\
\hline Vegetables & 560 & 2354.82 & 4.2 & 302 & 1234.22 & 4.08 & 190.4 & 492.37 & 2.58 \\
\hline Total & 1278.5 & 3712.19 & 2.9 & 958 & 2242.33 & 2.34 & 405.8 & 836.92 & 2.06 \\
\hline
\end{tabular}

Source: Data drawn from the final survey conducted in the three territories at the end of the project.

Associated with this, the sixth achievement is related to the significant reduction in the use of agrochemicals outside the biointensive garden (see Table 9). In 2017, 78.3\% of the survey respondents used chemicals for their agricultural activity, while today, only $38.6 \%$ of them apply chemical products to their conventionally farmed plots. It is a remarkable result at the local level, which may lead to economic savings and avoid possible environmental externalities, but it is also notable at a global level, because it proves that healthy food can be produced in sufficient amounts without incurring global environmental costs. There were people in various focus groups who declared that "the health of children, young people and adults in the household has improved by the consumption of chemical-free wholesome food".

Table 9. Percentage of families using agrochemicals.

\begin{tabular}{ccccc}
\hline & Madriz & Ometepe & Guatuzos & Total \\
\hline Before the project & 82.1 & 77.8 & 41.2 & 78.3 \\
After the project & 38.5 & 44.4 & 29.4 & 38.6 \\
\hline
\end{tabular}

Source: Data drawn from the two surveys conducted in the three territories at the beginning and the end of the project.

In summary, the project has achieved the implementation of the BM by 142 families of seven municipalities in three departments of Nicaragua. The average area cultivated by the families was $38.7 \mathrm{~m}^{2}$, with a standard deviation of $34.6 \mathrm{~m}^{2}$, and the average number of cycles per bed was 2.7 (see Table 10).

Table 10. An average number of beds and surface area per family, and average number of cycles per bed.

\begin{tabular}{cccc}
\hline Territories & $\begin{array}{c}\text { Average Number of } \\
\text { Beds Per Family }\end{array}$ & $\begin{array}{c}\text { Total Average Area Per } \\
\left.\text { Family } \mathbf{( m}^{\mathbf{2}}\right)\end{array}$ & $\begin{array}{c}\text { Average Number of } \\
\text { Cycles Per Bed }\end{array}$ \\
\hline Madriz & 3.72 & 38.92 & 2.81 \\
Ometepe & 3.85 & 38.52 & 2.46 \\
Guatuzos & 3.94 & 38.82 & 3.01 \\
Total & 3.84 & 38.75 & 2.76 \\
\hline
\end{tabular}

Source: Data drawn from the final survey conducted in the three territories at the end of the project.

Even though this will not have a global impact on this Central American country, it has certainly produced local benefits that represent an important step towards the ongoing improvement of food security in rural families with limited resources. Disaggregating the data by sex (see Table 11), we 
can see that, in general, women own a higher number of beds, with an average of 4 and a standard deviation of 2.3, while men only own 3.5 beds on average, with a standard deviation of 1.1.

Table 11. Average number of beds and surface area per family by the owner's gender.

\begin{tabular}{ccccc}
\hline Territories & \multicolumn{2}{c}{ Men } & \multicolumn{2}{c}{ Women } \\
\hline & $\begin{array}{c}\text { Average Number } \\
\text { of Beds Per Family }\end{array}$ & $\begin{array}{c}\text { Total Average } \\
\text { Area Per Family } \\
\left(\mathbf{m}^{\mathbf{2}}\right)\end{array}$ & $\begin{array}{c}\text { Average Number } \\
\text { of Beds Per Family }\end{array}$ & $\begin{array}{c}\text { Total Average } \\
\text { Area Per Family } \\
\left(\mathbf{m}^{\mathbf{2}} \mathbf{)}\right.\end{array}$ \\
\hline Madriz & 3.46 & 34.92 & 4.23 & 46.92 \\
Ometepe & 4.33 & 43.33 & 3.71 & 37.14 \\
Guatuzos & 3.2 & 32.0 & 4.25 & 41.67 \\
Total & 3.66 & 36.75 & 4.06 & 41.91 \\
\hline
\end{tabular}

Source: Data drawn from the final survey conducted in the three territories at the end of the project.

In this sense, we can affirm that women have devoted more time and attention to their gardens and have kept their beds growing crops during the whole year. This behavior is the outcome of greater emphasis on family integration and the administration of time devoted to garden tasks. In addition, it is possible to mention that biointensive gardens are seen by women as an excellent alternative to complement and diversify the family's production, as compared to men, who are still devoting more time to the conventional production of basic grains at the farm.

\section{Weaknesses in the Application of the Method}

A series of limitations have been observed in relation to the development of the biointensive method. First of all, the fieldwork, especially with the focus groups, has shown us that learning how to use and apply the method is a relatively slow process, and that not all trainees advance at the same pace, even if they all have gone through the same training with the same experts. This is due to the existence of barriers beyond information, training and the environmental characteristics of the different territories. The families' socioeconomic conditions, resources and life strategies are also key factors affecting people's behavior.

The final line study of the project reveals (see Table 5 ) that only $30 \%$ of the land was cultivated with carbon crops, $30 \%$ with calorie crops, and $40 \%$ with vitamin crops. This distribution is almost the opposite to the one initially proposed by the BM, and reflects the priorities of the participating families. However, it has been observed that, as long as the method is properly implemented, the output clearly improves in all cases.

Although the experience can be catalogued as a huge success in terms of food production (diversity, and in many cases, quantity as well), the above-mentioned opposite distribution formula raises the following questions, some of them posed in the focus groups. What is the problem in introducing external carbon sources in the BM? The experts involved in the project affirmed that if we did, we would not be dealing with a closed system anymore, a system in which the soil itself guarantees self-sufficiency: By preserving its ideal composition, and at the same time, producing enough food for the people who manage it. This break with the basic principle of the BM "could be accepted as a necessary measure in the transition from food insufficiency to food self-sufficiency", was the answer of local leaders who worried more about obtaining food today than about meeting the guidelines of the BM.

Secondly, and connected with the above, in several focus groups and in-depth interviews, the need to tropicalize the method was underlined. Tropicalization would possibly imply the introduction of some covering for the biointensive beds, as a measure to protect them by reducing the adverse effects of the extreme climate conditions of the Dry Corridor in Nicaragua. In addition, in the tropics, in contrast to temperate regions, there are three well-differentiated crop seasons, which coincide with the periods in which access to water is easier. During the summer, only those producers who have access to water can risk planting some crops (in certain areas, rainwater harvesting was integrated 
into the biointensive processes). Finally, building beds in sloping or uneven topographies imposes severe restrictions to double digging: In some communities, it was performed on the soil surface, not in depth. This also added certain particularities to the application of the BM in these tropical areas, somehow limiting its progress and consolidation.

On the other hand, in the process of adapting the method to the tropics, we observed that the results are different in what concerns diversity and the area required to achieve sufficiently high levels of production to comply with the demand of food of those who manage the gardens. Jeavons estimated that, as an average for northern California, USA, 40 beds of $10 \mathrm{~m}^{2}$ each per person were required to guarantee enough biomass for compost to replace that which was extracted from the soil during the production process, and at the same time, produce enough food for the people cultivating the land. Franck Tondeur, an expert in biointensification working in Nicaragua, has concluded that "in our environment [the tropics], this area is reduced to 15 beds or the equivalent to 150 to $200 \mathrm{~m}^{2}$ in terraces". In other words, the tropicalization of the method also entails a difference in the size of the total area required to produce what is needed to achieve food self-sufficiency for the producer.

In all focus groups, the same conclusion was drawn. Even if the BM has brought a transformation to the family food system, the scope of its effects has been limited, and its consolidation at a community and municipal level requires a medium-term institutional strategy. Two years is a short time, and the technological support must be wider and long-lasting, including more training and reaching other communities within the municipality. The groups concluded that "the full incorporation of the system or the coming closer to sustainability will only be possible within a time period that exceeds those of traditional (cooperation) projects". Given the social characteristics of the households participating in this project, a period of approximately 6 to 8 years is required for the community to attain sustainability, in the sense of food self-sufficiency for the people working the land and the capability of the soil to preserve all its attributes.

From our point of view, a territorial development strategy designed by the communities for all municipalities, regions and the whole national territory would be the best way to advance self-sufficiency in this double direction (food and soil) facilitated by the BM. However, this would require substantial changes in the institutional sphere. As pointed out by various sources, the government of Nicaragua is presently implementing a capitalist development model combined with assistance-oriented social policies prone to clientelism, for the purpose of managing rural poverty by imposing top-down policies, repressing the most militant opposition groups, and forging alliances with the traditional economic sectors [44]. All of this is far from the economic and political empowerment of local communities promoted by decentralized innovative technologies and social processes like the BM.

\section{Conclusions}

Agroecology, and in particular, the biointensive method of food production have proved to be an appropriate solution to put an end to food insecurity, and at the same time, carry out the technological and environmental transformations required in the current context of climate change. The assessment of the implementation of the BM in seven municipalities located in the Dry Corridor of Nicaragua allows us to affirm that household food availability, variability and security have all improved. This has been achieved through the valuation of women's role in the economic development of their families, and the diversification of the families' sources of income. The resulting surplus income has enabled the acquisition of other food and services that significantly contribute to improving the quality of life of these families.

With regard to production, deep technological and process-related changes have been observed. On the one hand, there was an increment of self-sufficiency in seed production, which led to the creation of new local seedbanks with women's active participation. In addition, waste management has also been improved with the introduction of new recycling systems that transform waste into organic fertilizers via composting. The benefits of this procedure have been observed both in biointensive gardens, where the productivity level surpassed that of the conventional production areas, and in 
those conventionally farmed areas as well, where a decrease in the use of inorganic fertilizers has been reported.

However, it has become evident that the families have worked for the availability of food in the short-term, because "eating comes first". This has been achieved by not complying to the $60 \%-30 \%-10 \%$ rule; in consequence, there is a possibility that the system will collapse in the medium-term. Nevertheless, two years is clearly too short a period to assess the technical viability of a proposition like the BM. Both [42], who developed an 8-year-long biointensive crop project, and [45], who led a 6-year-long experiment, had already pointed in that direction. In this sense, it is important to underline that the main obstacle that the BM has faced in the Dry Corridor of Nicaragua was the distance separating the original formulation from the environmental and social reality of this tropical region. Therefore, according to the evaluation made, the tropicalization of the BM is the project's most important challenge, confirming once again that there are no one-way solutions for all territories and socioeconomic circumstances. Local practices and dynamics, as seen during these two years, have inevitably brought about changes in the BM. This has made it possible to anticipate new ways of reducing food insecurity among low-income families with limited resources.

Supplementary Materials: The following are available online at http://www.mdpi.com/2071-1050/12/3/844/s1, Table S1. Main results derived from in-depth interviews.

Author Contributions: M.M. was responsible for compiling the bibliography, looking for external inputs (such as national statistics and reports from international organizations); Ó.B. coordinated the fieldwork and the statistical analysis with the collaboration of M.M; X.S. was in charge of conceptualizing the social problem under analysis, the analysis itself, and the writing; Draft versions were reviewed by all the authors. Ó.B. and the Nicaraguan Team managed the global project, including the funding. All authors have read and agreed to the published version of the manuscript.

Funding: This research was funded by the Spanish Agency of International Cooperation for Development (AECID), grant number 2016/ACDE/002460 through the project "Biointensive Method: Innovation for agroecologic food production at a family scale in Nicaragua".

Acknowledgments: We are very grateful to all the rural families that have taken part in the project, opening their humble houses and small landplots to us. Had it not been for them, the entire project and this article would not have been possible. Technicians and staff from ECOPOL, UNA, INPRHU, Red de Mujeres de Ometepe (REMO) and Fundación Entre Volcanes were always willing and able to help us understand the local social processes and overcome the challenges we faced.

Conflicts of Interest: The authors declare no conflict of interest.

\section{References}

1. Holt-Giménez, E.; Shattuck, A.; Altieri, M.; Herren, H.; Gliessman, S. We already grow enough food for 10 billion people ... and still can't end hunger. J. Sustain. Agric. 2012, 366, 595-598. [CrossRef]

2. FAO; IFAD; UNICEF; WFP; WHO. The State of Food Security and Nutrition in the World 2018: Building Climate Resilience for Food Security and Nutrition; FAO: Rome, Italy, 2018.

3. International Food Policy Research Institute (IFPRI). Sustainable Food Security for All by 2020; International Food Policy Research Institute: Washington, DC, USA, 2002.

4. Bacon, C.M.; Sundstrom, W.A.; Flores Gómez, M.E.; Méndez, V.E.; Santos, R.; Goldoftas, B.; Dougherty, I. Explaining the 'hungry farmer paradox': Smallholders and fair trade cooperatives navigate seasonality and change in Nicaragua's corn and coffee markets. Glob. Environ. Chang. 2014, 25, 133-149. [CrossRef]

5. FAO; OPS; WFP; UNICEF. Panorama de la Seguridad Alimentaria y Nutricional en América Latina y el Caribe 2018; FAO: Santiago, Chile, 2018.

6. World Bank. Nicaragua. Paving the Way to Faster Growth and Inclusion. Systematic Country Diagnostic. Available online: https://openknowledge.worldbank.org/bitstream/handle/10986/27560/Nicaragua-SCDCopyedit-final-jun-20-06272017.pdf?sequence=1\&isAllowed=y (accessed on 15 March 2019).

7. Parfitt, J.; Barthel, M.; Macnaughton, S. Food waste within food supply chains: Quantification and potential for change to 2050. Philos. Transit. R. Soc. B 2010, 365, 3065-3081. [CrossRef] [PubMed]

8. Shiferaw, B.; Prasanna, B.M.; Hellin, J.; Bänziger, M. Crops that feed the world 6. Past successes and future challenges to the role played by maize in global food security. Food Secur. 2011, 3, 307-327. [CrossRef] 
9. Stoatea, C.; Boatmana, N.D.; Borralhob, J.; Rio Carvalho, C.; de Snoo, G.R.; Eden, P. Ecological impacts of arable intensification in Europe. J. Environ. Manag. 2001, 634, 337-365. [CrossRef]

10. Rockstrom, J.; Steffen, W.; Noone, K.; Persson, Å.; Chapin, F.S., III; Lambin, E.; Lenton, T.M.; Scheffer, M.; Folke, C.; Schellnhuber, H.J.; et al. Planetary boundaries: Exploring the safe operating space for humanity. Ecol. Soc. 2009, 142, 472-475. [CrossRef]

11. WTO. Annual Report. Available online: https://www.wto.org/english/res_e/booksp_e/anrep19_e.pdf (accessed on 17 August 2019).

12. Inter-American Institute for Cooperation on Agriculture (IICA). 2018-2022 Medium-Term Plan; Inter-American Institute for Cooperation on Agriculture: San José, Costa Rica, 2018.

13. Economic Commission for Latin America and the Caribbean (ECLAC). Climate Change in Central America: Potential Impacts and Public Policy Options; Economic Commission for Latin America and the Caribbean: Mexico City, Mexico, 2015.

14. Calvo-Solano, O.D.; Quesada-Hernandez, L.; Hidalgo, H.; Gotlieb, Y. Impactos de las sequías en el sector agropecuario del Corredor Seco Centroamericano. Agron. Mesoam. 2018, 293, 695-709. [CrossRef]

15. Tranchant, J.P.; Gelli, A.; Bliznashka, L.; Sekou Diallo, A.; Sacko, M.; Assima, A.; Aurino, E.; Masset, E. The impact of food assistance on food insecure populations during conflict: Evidence from a quasi-experiment in Mali. World Dev. 2019, 119, 185-202. [CrossRef]

16. Doocy, S.; Emerson, J.; Colantouni, E.; Strong, J.; Mansen, K.A.; Caulfield, L.E.; Klemm, R.; Brye, L.; Funna, S.; Nzanzu, J.P.; et al. Improving household food security in eastern Democratic Republic of the Congo: A comparative analysis of four interventions. Food Secur. 2018, 103, 649-660. [CrossRef]

17. Gilbert, N.; Gewin, V.; Tollefson, J.; Sachs, J.; Potrykus, I. How to feed a hungry world. Nature 2010, 466, 531-532.

18. Pretty, J. Intensification for redesigned and sustainable agricultural systems. Science 2018, 362. [CrossRef] [PubMed]

19. Altieri, M. Agroecología. Bases Cientificas para una Agricultura Sustentable; Ediciones CETAL: Valparaíso, Chile, 1983.

20. Rosset, P.; Altieri, M.A. Agroecology: Science and Politics; Fernwood Publishing Company Limited: Winnipeg, MB, Canada, 2017.

21. Francis, C.; Lieblein, G.; Gliessman, S.; Breland, T.A.; Creamer, N.; Harwood, R.; Salomonsson, L.; Helenius, J.; Rickerl, D.; Salvador, R.; et al. Agroecology: The ecology of food systems. J. Sustain. Agric. 2003, 223, 99-118. [CrossRef]

22. Wezel, A.; Bellon, S.; Doré, T.; Francis, C.; Vallod, D.; David, C. Agroecology as a science, a movement, and a practice. A review. Agron. Sustain. Dev. 2009, 294, 503-515. [CrossRef]

23. Giraldo, O.F.; Rosset, P.M. Agroecology as a territory in dispute: Between institutionality and social movements. J. Peasant Stud. 2017, 453, 545-564. [CrossRef]

24. Sage, C. The interconnected challenges for food security from a food regimes perspective: Energy, climate and malconsumption. J. Rural Stud. 2013, 29, 71-80. [CrossRef]

25. Sonnino, R.; Torres, C.L.; Schneider, S. Reflexive governance for food security: The example of school feeding in Brazil. J. Rural Stud. 2014, 36, 1-12. [CrossRef]

26. La Vía Campesina. Declaration of the International Forum for Agroecology. Available online: https: //viacampesina.org/en/declaration-of-the-international-forum-for-agroecology/ (accessed on 3 February 2019).

27. Crimi, S.J. (Ed.) Performance in the Garden. A Collection of Talks on Biodynamic French Intensive Horticulture. Lectures by Alan Chadwick. Available online: http://www.alan-chadwick.org/html\%20pages/ books_articles/performance_in_the_garden.html (accessed on 25 July 2019).

28. Jeavons, J.C. Biointensive sustainable mini-farming: I. The challenge. J. Sustain. Agric. 2001, 192, 49-63. [CrossRef]

29. Drewno, M. Achieving More with Less: Experiments in Growing a Complete Diet in 1000 Sqft; Ecology Action: Willits, CA, USA, 2017.

30. Jeavons, J.C. Biointensive sustainable mini-farming: II. Perspective, principles, techniques and history. J. Sustain. Agric. 2001, 192, 65-76.

31. Jeavons, J.C. Biointensive sustainable mini-farming: III. System performance-initial trials. J. Sustain. Agric. 2001, 192, 77-83. 
32. Jeavons, J.C. Biointensive sustainable mini-farming: IV. System performance-continuing trials in a more difficult environment and soil. J. Sustain. Agric. 2001, 192, 85-97.

33. Gómez-Álvarez, R.; Lázaro-Jerónimo, G.; León-Nájera, J.A. Producción de Frijol Phaseolus vulgaris L. y Rábano Rhabanus sativus L. en Huertos Biointensivos en el Trópico Húmedo de Tabasco; Universidad y Ciencia: Villahermosa, Mexico, 2008; Volume 241, pp. 11-20.

34. Moore, S.R. Energy efficiency in small-scale biointensive organic onion production in Pennsylvania, USA. Renew. Agric. Food Syst. 2010, 253, 181-188. [CrossRef]

35. IAASTD. Agriculture at a Crossroads; IAASTD Findings and Recommendations for Future Farming; IAASTD: Washington, DC, USA, 2016.

36. Jeavons, J. How to Grow More Vegetables, 9th ed.; Ten Speed Press: Berkeley, CA, USA, 2017.

37. Ministerio del Medio Ambiente y Los Recursos Naturales (MARENA). Reservas de Biosfera Bosawas y Río San Juan. Available online: http://www.marena.gob.ni/wp-content/uploads/2019/04/Presentacion-BosqueBosawas-RioSanJuan.pdf (accessed on 1 August 2019).

38. Cook, C.D.; Hamerschlag, K.; Klein, K. Cultivando para el Future; Amigos de la Tierra: Madrid, Spain, 2017; Available online: https://www.tierra.org//wp-content/uploads/2017/04/Informe-CULTIVANDO-PARA-ELFUTURO.pdf (accessed on 14 August 2019).

39. Amigos de la Tierra. Alimentos Kilométricos; Amigos de la Tierra: Madrid, Spain, 2008; Available online: https://www.tierra.org//wp-content/uploads/2016/01/informe_alimentoskm.pdf (accessed on 8 August 2019).

40. Johnson, R.B.; Onwuegbuzie, A.J.; Turner, L.A. Toward a definition of mixed methods research. J. Mix. Methods Res. 2007, 12, 112-133. [CrossRef]

41. Holt-Giménez, E. Campesino a Campesino: Voces de Latinoamérica Movimiento Campesino para la Agricultura Sustentable; SIMAS: Managua, Nicaragua, 2008.

42. Medina Macías, J.A. de la Producción de Biomasa y su Relación con las Propiedades del Suelo en un Sistema de Cultivo Biointensivo; Centro de Ciencias Agropecuarias: Aguascalientes, México, 2015.

43. Schmeer, K.K.; Piperata, B.A.; Herrera Rodríguez, A.; Salazar Torres, V.M.; Centeno Cárdenas, F.J. Maternal resources and household food security: Evidence from Nicaragua. Public Health Nutr. 2015, 1816, 2915-2924. [CrossRef] [PubMed]

44. Martí i Puig, S.; Baumeister, E. Agrarian policies in Nicaragua: From revolution to the revival of agro-exports, 1979-2015. J. Agrar. Chang. 2017, 17, 381-396. [CrossRef]

45. Figueredo Rodríguez, M.; Cuevas Vázquez, M.; Serrano Flores, M.E.; Hernández Soto, J.A. Análisis de los rendimientos y comportamiento de las propiedades del suelo mediante la aplicación de la agricultura orgánica biointensiva. Cent. Agríc. 2004, 311-312, 104-108. 